\title{
The Art of Music in the Period from Monteverdi to Bach
}

Jurij Snoj. The Art of Music in the Period from Monteverdi to Bach. [Umetnost glasbe $v$ času od Monteverdija do Bacha.] (Ljubljana: ZRC Publishing House, ZRC SAZU, 2017. 632 pages. 37,00 €. ISBN: 978-961-254-998-5).

The monograph The Art of Music in the Period from Monteverdi to Bach by Jurij Snoj is an original scientific work that brings an in-depth review of the history of European art music during the Baroque Period. In recent times, quite a few scientific monographs about the Baroque Period have been published in English and in other languages, ${ }^{1}$ which proves that alongside partial research, there is also a need for synthesising scientific surveys of events across broader timespans - surveys that are based on new insights and more recent interpretations. Snoj's book certainly must be placed in this circle of literature, especially as it advances Slovenian scientific historiography. In this context, the ground-breaking music history by Vilko Ukmar ${ }^{2}$ must be mentioned, as well as the translations by Primož Kuret and some profound segments in the discussions by Jože Sivec, Edo Škulj, Metoda Kokole and others.

As the author reminds us in the foreword of this monograph, the history of European music as a topic of discussion, in its physical form consists of numerous manuscripts, prints and contemporaneous texts that were in some way connected to music. The main problem with more extensive music-historical descriptions is that there is no generally accepted methodology, although there are extensive attempts and approaches. Although there are numerous topics in music history that cannot be overlooked, the surveys of music history are unavoidably selective. Consequently, any overview of music history is necessarily a compilation of different music-historical surveys, corresponding monographs and articles from the most important scientific encyclopaedias. On the other hand, comprehensive music-historical accounts cannot be "merely" a compilation, because of the multitude of topics and methodologies of contemporary musical-historical knowledge required by the author.

Snoj is fully aware of the diversity of approaches and views, from which specific topic-questions arise, which he takes into an account when considering his answers.

1 George J. Buelow, A History of Baroque Music (Bloomington: Indiana University Press, 2004); Tim Carter and John Butt (Eds), The Cambridge History of Seventeenth-Century Music (Cambridge: Cambridge University Press, 2005); John Walter Hill, Baroque Music: Music in Western Europe 1580-1750 (New York and London: Norton, 2005); George B. Stauffer (Ed.), The World of Baroque Music: New Perspectives (Bloomington and Indianapolis: Indiana University Press, 2006); Richard Taruskin, The Oxford History of Western Music, 2: The Seventeenth and Eighteenth Centuries (Oxford and New York: Oxford University Press, 2005).

2 Vilko Ukmar, Glasba v preteklosti [Music in the Past] (Ljubljana: Državna založba Slovenije, 1972). 
The monograph summarises corresponding contemporary scientific literature (cited in the extensive bibliography on pages 606-610). His work is indeed not only a compilation of contemporary knowledge, but comprises numerous original segments, such as different analytical-critical presentations of musical works (e.g. Monteverdi's Madrigal Ohimè, dov'è il mio ben on pages 89-91 etc.) and commentaries on the lives and works of composers that are the result of the author's own research. In this manner, Snoj constantly conjoins contemporary knowledge with his analytical results about the Baroque Period.

The book is divided into three larger segments: the first is dedicated to the epoch-making novelties in Italian music at the turn of the seventeenth century; the second describes the music of the seventeenth century in four main musical centres of Europe - Italy, the German lands, France, England; and the third deals with music in the first half of the eighteenth century, when a stabilisation of internationally recognised genres and musical forms emerged. He seeks to combine separate sections into a unified historical narrative, as much as possible, but any historical account comprises varied concepts, and the book therefore consists of nineteen chapters in chronological order, with the descriptions of phenomena alternating between the above-mentioned countries.

The book combines diverse content in an original manner: there are descriptions of musical life in chosen historical milieus, such as the management of important chapels and the way theatre and theatre performances function. This relates to many descriptions of musical genres, and the concept of genre plays the most important part in the book because it is closely related to the idea that all music should fulfil a certain function in its given environment.

The author also offers a convincing account of individual historical forms of music, and their formation and development. Since composed music is discussed, the work contains numerous presentations of composers, which are precise and designed to elaborate on the circumstances in which the composers satisfied the musical needs of their community (e.g. chapter "Venetian Opera and Its Social Position" on pages 157-9). Compared to some other similar music history surveys, Snoj's work does not avoid detailed theoretical explanations or conceptualizations that are crucial for an in-depth understanding of specific topics.

Each description of a composer features a detailed outline of his opus. Furthermore, the monograph also contains a set of analytical and critical descriptions of chosen compositions that illustrate specific forms and genres (e.g. chapter "Oratorio", see pages 193-201), or even the personalities of the composers. In this respect, there is an apparent lack of examples with notations that would be hugely helpful in providing the reader with a better understanding and illustration of the presented analytical and theoretical interpretations. Admittedly, such an expansion would lengthen the book's already considerable page count (632), and open a Pandora's box of subsidiary rights and other publishing demands - complications that the authors of such extensive monographs usually avoid.

The book elaborates on material that is of interest to the specialized and professional readership, as well as the broader intellectual public that is interested in music and 
cultural history from the late sixteenth until the mid eighteenth centuries. Alongside the author's typical interpretative precision and systematic approach, the book is characterised by scientific irreproachability - both in the sense of methodological clarity and insights, as well as in all other elements of scientific information communication. Snoj's style has the ease of language that effortlessly masters dilemmas arising from the discussion of wide-ranging topic that incorporate history, aesthetics and the sociology of music, but first and foremost music theory, morphology and analysis.

Moreover, the author finds appropriate and well-grounded terms for several concepts discussed in Slovenian for the first time. For instance, in the chapter about the outline of the book (a kind of introduction), Snoj emphasizes that a thorough Slovenization proved to be problematic because some names (e.g. the foreign citations of Latin liturgical texts that can be understood only in the specific context of Latin liturgy, as well as some titles of operas and other works) cannot be translated accurately. For this reason, all titles in the monograph, Slovene or not, are italicized. What is more, most of the existing terminology of music history is thought over and adjusted accordingly. For the sake of clarity, the now combined indexes (author and subject) could be separated. But the present system does enable the reader to browse easily through information about specific persons or concepts. Finally, the clear visual and graphic design of the book should be commended.

As the first survey of a specific period of music history by a Slovene author, the monograph will profoundly enrich the bibliographies of all subjects related to older music at Slovene universities and further afield. 